\title{
A NEW SIMPLE PROOF OF WILKER'S INEQUALITY
}

\author{
LING ZHU
}

Abstract. In this note, we show a new simple proof of Wilker's inequality.

Mathematics subject classification (2000): 26 D15.

Key words and phrases: Wilker's inequality.

\section{REFERENCES}

[1] J. B. Wilker, E3306, The American Mathematical Monthly, 96, 1 (1989), 55.

[2] J. S. Sumner, A. A. Jagers, M. Vowe And J. Anglesio, Inequalities involving trigonometric functions, The American Mathematical Monthly, 98, 3 (1991), 264-267.

[3] B. N. GUO, B. M. QIAO, F. QI AND W. LI, On new proof of Wilker's inequalities involving trigonometric functions, Mathematical Inequalities and Applications, 6, 1 (2003), 19-22.

[4] D. S. Mitrinović, Analytic Inequalities, Springer-Verlag, 1970.

[5] P. S. Bullen, Handbooks of Means and Their Inequalities, Kluwer Academic Publishers, 2003. 